\title{
Fourth IIGS International Conference on the Muslim World
}

\author{
18-22 December 1995/25-29 Rajab 1416 \\ Al al-Bayt University, Amman, Jordan
}

The Fourth International Conference on the Muslim World, organized by the Intemational Islamic Geographic Society, was hosted by Al al-Bayt University, Amman, Jordan. This four-day conference brought together a distinguished international gathering of geographers and social scientists to discuss issues of concem to Muslim countries. The conference was held in a very pleasant, cordial, and hospitable environment, and the excursion trip at its end, which provided an opportunity to visit historical places and archaeological sites, made it all the more enjoyable and memorable.

The conference was comprised of five regular sessions and featured sixteen presentations before a select audience of no more than fifty individuals. Mohammad Adnan Al-Bakhit, president of Al al-Bayt University, gave the welcoming address. He greeted the participants wamly and expressed the hope that this conference would promote research and motivate young Muslim geographers to undertake scholarly pursuits. He said that the university is committed to promoting scientific research, with an Islamic outlook, in all fields of knowledge. Mushtaqur Rehman, IIGS secretary and prominent Muslim geographer and anthropologist, pronounced the conference's theme, highlighted its multidisciplinary dimensions, and elaborated on its significance to the Muslim world, which has serious developmental problems.

The first session, chaired by Rehman, started with Hussain A. Amery's insightful examination of water management in the geopolitical context of the Middle East. He emphasized the need for cooperation among the region's Muslim states and the use of new technologies for harvesting water and treating waste water for reuse. A. R. Hamideh focused on the issue of population growth in Muslim countries and refuted categorically the argument of Western anthropologists that the Islamic value system is a major obstacle in dealing with demographic issues.

Session two was chaired by Hani D. Tabba and featured three presentations. A. Hussain examined the nation-state in a historical perspective and argued that unless Muslim countries abandon this structure, they will be unable to establish an Islamic Common Market and will not achieve economic development. Abdel Bagi investigated the socioeconomic problems of rural-urban migration, largely due to desertification, in Sudan. He suggested the formulation of policies designed to revitalize the rural economy 
and thereby reverse this migration. Salman Abu Settah examined the Palestinian Holocaust of 1984 and deplored the media's efforts to keep the Jewish Holocaust alive while largely ignoring Palestinian massacres, suffering, and humiliation which has been forgotten by the world. Rasheed AlFeel discussed Muslim problems in a geographical context and concluded that they could be resolved by mobilizing resources and promoting interMuslim trade.

Session three was chaired by Omar Shadaifat and included two presentations. Ruel Hanks gave an objective assessment of Uzbekistan's contemporary sociopolitical environment and concluded that the present Islamist-secular confrontation will soon end, marking a clear victory for those committed deeply to an Islamic way of life. Ahmad Agala examined Jordan's political system and observed that popular participation in Jordan is far higher than in many Muslim republics. Yaser M. Najjar evaluated Jordan's development planning and remarked that a capital-poor country like Jordan cannot achieve industrialization without borrowing high-cost capital and technology from abroad. He suggested that economic cooperation among Muslim countries could help resolve the problem of capital scarcity. S. Ali Khan investigated the process of development from the capitalist and Islamic perspectives. He pointed out that material well-being is capitalism's only goal, whereas the Islamic approach stresses the realization of both material and spiritual well-being. He also stated that the realization of both goals is possible only through restructuring the existing political and economic institutions within the context of an Islamic social order.

Session four, chaired by Sayyid M. Ahmad, featured two papers. Abdullah Al-Tarazi examined the issue of Jewish settlements in the midst of Palestinian populations and the resulting socioeconomic tensions. $\mathrm{He}$ concluded that, due mainly to the acute shortage of water, the economies of these areas are unsustainable. Konard Schiephake revealed that the Saudi economy has become less oil-export dependent due to its expanded industrial base. Quite surprisingly, he drew the rather simplistic conclusion that the Islamic value system is flexibile enough to accommodate the capitalistic mode of industrialization. Amriah Buang examined the development process in Malaysia and noted that it has made significant progress by seeking a compromise between Islamization and Westernization. Two questions that were left unanswered in this very interesting presentation are: Does Malaysia present a reasonable description of the Muslim world, or does this study offer a model for Muslim countries having socioeconomic conditions that are quite different from those of Malaysia?

Session five was chaired by Rasheed Al-Feel and included three presentations. Abdul Qadir Saleh spoke on the problems of land use in Jordan. After surveying the Jordan Valley's geographical features, he suggested that land distribution among agriculture, industry, and urbanization should be based on efficiency, permanency, and justice. Mohammad Said examined problems created by natural hazards in Pakistan's northern region and recommended the use of modern technology to predict changes 
in nature and to minimize losses of human life, property, and industrial infrastructure. Ali Basiouni ended the session by examining the capitalistbased growth of Bahrain's economy. He pointed out that an increase in the production of value-added exportable goods has resulted in higher employment and higher income.

In session six, the IIGS held its business meeting, during which it examined its past performance, discussed future plans, and elected a new executive body for 1996-2000. Its members consist of Mushtaqur Rehman (president), Ali Basiouni (vice president), Yaser Najjar (secretary), and Amriah Buang (treasurer).

In the final session, Al-Bakhit delivered an inspiring keynote address and commended the efforts of IIGS as well as the participants' intellectual contributions. He noted that the conference had provided an opportunity to Jordanian geographers and social scientists to learn from the knowledge, experience, and expertise of pioneers in their chosen fields. He reaffirmed that $\mathrm{Al}$ al-Bayt University will publish the proceedings and papers to advance knowledge through research. Rehman acknowledged the warm welcome and hospitality of $\mathrm{Al}$ al-Bayt University and thanked its president for hosting the conference and making the necessary arrangements.

At the end of the concluding session, several resolutions were passed. It was resolved that professional Muslim organizations and universities must work together to prepare an exciting agenda and provide facilities to young Muslim researchers to motivate them to develop theoretical and practical models and to seek solutions to many problems facing the contemporary Muslim world. It was also resolved to provide an agenda for action to policy makers in the Muslim world and to seek sustained development through mutual cooperation and facilitating the transfer of knowledge and free movement of resources among Muslim countries.

In the final analysis, this conference provided a forum for Muslim scholars to discuss issues, exchange views, and enhance their understanding of the many common problems facing Muslim countries. Though most of the presentations lacked a clear Islamic orientation, the quality of papers was good. Abstract theoretical discussions were kept to a minimum, as rigorous analysis of issues was not the main goal. This purely substance-oriented approach made the discussion routine and the question-answer sessions uninspiring. There were no workshops and, hence, no opportunities for the audience to gain a deeper and wider understanding of the models and viewpoints presented during the short regular sessions.

Shujaat A. Khan Department of Economics St. John's University Brooklyn, New York 